\title{
COMPETING OR HARMONIC? EVOLUTION AND ORIGINAL SIN IN THE AUGUSTINIAN/REFORMED TRADITION
}

\author{
MARCELO CABRAL \\ https:/ / orcid.org/0000-0001-5761-5637 \\ University of Campinas \\ Department of Philosophy \\ Campinas, S.P. \\ Brazil \\ marcelobc87@gmail.com
}

\begin{abstract}
Article info
CDD: 189.2

\section{Keywords \\ Augustine \\ Doctrine \\ Original Sin \\ Reformed Tradition \\ Evolutionary Theory \\ Narrative}

Received: 07.04.2021; Revised: 12.07.2021; Accepted: 27.07.2021

https://doi.org/10.1590/0100-6045.2021.V44N4.MB

\begin{abstract}
The complex relations between Christianity and science seem to present a critical point in evolutionary theory, especially for the challenges it poses to the doctrine of original sin. I investigate the precise senses in which evolution threatens (or not) the Augustinian/Reformed formulation of original sin, analyzing each of the six tenets of the doctrine vis a vis nine evolutionary claims, as well as the supposed clash between the narratives of evolution and Christianity. I show that the threat is less impressive than it is usually assumed, and I highlight where the conflict really lies. I defend that it is possible to remain faithful to the core of the doctrine of original sin and to accept the reliability of evolution as a scientific theory. I present three scenarios for "Adam and Eve" and interpret them using two different models. I favor the
\end{abstract}


understanding of Adam and Eve as the whole initial human bottleneck viewed through the lens of a multilevel model.

\section{Introduction}

It is beyond any reasonable doubt that one of the most significant scientific proposals of the last two hundred years is Darwin's theory of evolution, first advanced in his Origin of Species in 1859. Since then, evolutionary theory has been going through important advancements, corrections, small tweaks, and a fundamental merger with genetics, making it one of the most solid theories at the bar of the sciences. But if evolution is widely accepted and supported within the scientific community, the same cannot be said of its reception by Christian believers. From its beginning, Darwin's theses had their defenders and strong opponents among Christians, which continues to this day. But why exactly? Why have many Christians considered evolution unfitted to the teachings of the Bible? Among the numerous issues that are at stake, the Christian doctrine of original sin and its sibling, the doctrine of fall, seem to be at center stage.

The central purpose of this paper is to investigate the following question: considering that the major claims of evolutionary science on human origins are accurate, can the Augustinian/Reformed formulation of original sin still stand up? In order to offer a proper response we need to explore which beliefs are essential and which are incidental to the Augustinian/Reformed tradition (hereafter ART).

As it is clear from this proposal, I will not investigate the allegations from science in defense of (or against) evolution. I will take the main claims of evolutionary theory for granted, although I will briefly explain where some of the critiques come from and their aims. A second important strategy for this paper is to investigate original sin not as a singular belief, 
but rather as both a cluster of beliefs dealing with the sinful condition of humanity and as a part of a cosmological narrative which is central to the biblical vision of human history. In this paper I draw heavily on the work of philosophers and theologians who have been working on this topic. Jaeger (2017) and Collins (2018) provide valuable overviews of proposals in the literature, as well as put forward their own particular theories, which I discuss in some detail. Smith (2017) is distinctive in his emphasis on the narrative aspect of original sin, and how it can accommodate evolutionary science. Pinsent (2018) describes and discusses the Augustine version of original sin, and van den Brink (2018) devises a methodology of describing original $\sin$ as a number of interconnected claims - a methodology that is fundamental for this paper. Harlow (2010) and Schneider (2012) are important representants of a position that I will reject - that the truth of evolution demands abandoning the Augustinian/Reformed understanding of original sin altogether.

There is an important reason for targeting specifically the ART. Augustine should not be considered the "inventor" of the doctrine of original sin. Rather, he was a compiler of previous insights and the one who has bequeathed its main formulation to the West (McCoy 2014). The documents produced in the context of the Continental Reformed movements in the sixteenth century drew heavily on Augustine's legacy, and they are still sources of theological, doctrinal, and liturgical inspiration for Christians way beyond the boundaries of Reformed denominations. Interestingly also is the growing impact that such documents have exercised in countries beyond USA and Europe, such as Brazil, where evangelicals, growing at high rates in the last three decades, are now experiencing a curious interest in the Reformed tradition, its documents and theological formulations. 
The main assumption of this paper is that it is possible to remain within the boundaries of the ART if, and only if, the way we understand the impact of evolutionary theory (hereafter ET) on original sin does not entail abandoning the biblical cosmological narrative of creation, fall, redemption, and consummation, and if it does not contradict the main beliefs that compound the doctrinal cluster of original sin. I will argue that we are entitled to reinterpret some of those beliefs in light of evolution, and to reimagine the narrative details in some terms. My conclusion will be that it is possible to remain committed to the doctrine of original sin and to accept ET.

The paper is structured as follows. First, I offer an overview of ET's main claims on the evolution of Homo sapiens. Second, I present the doctrine of original sin in its Augustinian and Reformed tones. Third, I explore how ET impinges upon the doctrine, highlighting the main challenges brought up by it. Fourth, I present some Christian responses to these challenges, first by sketching some accounts of incompatibility and then suggesting ways forward of compatibility.

\section{Part 1: What Evolutionary Science Says About Human Origins}

ET says that 1) our species, Homo sapiens, shares a common ancestry with all other living (and dead) species on the planet; 2) exactly as with all other species, the main mechanism that drove our development was natural selection; 3) random mutations within our genetic material were the means by which our biological ancestors acquired new traits that were privileged by means of natural selection; 4) our species first emerged in Africa between 300,000 and 200,000 years ago; 5) our species did not emerge as a single 
pair of individuals, but rather as a bottleneck of at least 10,000 individuals; 6) many other hominin species existed before our own had emerged, and some of them existed for some time along with ours; 7) there was interbreeding between our species and other hominin species, so that there are living people today who have a share of their genes acquired from other hominin species; 8) death was present in the natural world much long our species emerged-or even had the chance to sin; and 9) traits such as hunting, aggression, sexual promiscuity, among others, were inherited by our species from our biological ancestors and were important characteristics for the success (preservation) of our species. ${ }^{1}$ I shall briefly comment on some of these topics.

1), 2), and 3) are simply the overall claims of ET for all species and biological processes at work in our world. 1) and 2) were proposed by Darwin himself, while 3) was later added to the theory based on developments in genetic science. They together mean that our species did not appear overnight in a special, unique act of creation, but rather, "evolved gradually over the course of six million years" (Harlow 2010, p. 179).

Claims 4) and 5) are now largely confirmed by both the fossil record and genetic analyses. On the fossil record, while until some decades ago there were few relevant findings, recent discoveries, especially in the Rift Valley of Africa, provide significant evidence (Falk 2017, pp. 6-7). Remarkable as the fossil evidence is, the genetic evidence is even more impressive (D. Venema and S. McKnight 2017, p. 11). Claim 8) is straightforward and predates Darwin himself: physical death is part of the fabric of the world rather than some strange intruder. Finally, 9), along with 8), makes it clear that some things we have considered as bad

1 These aspects of ET are well presented and summarized by D. Falk (2017). 
actions, evil inclinations, or, theologically, sinful dispositions, are part of our historical development and essential to our survival as a species (Van den Brink 2018, p. 125).

\section{Part 2: Original Sin}

\subsection{Sin Unrestricted}

"By its nature the evidence of Eden is something that one cannot find. By its nature the evidence of sin is something that one cannot help finding", elegantly declared G. K. Chesterton (1915, pp. 191-192). For him, Christianity's allegation about the pervasiveness of sin is impossible to be denied: injustice, pain, suffering, evil, and all sorts of tragedies are as ubiquitous as is the human presence in the world.

Original sin, however, is a doctrine that makes claims not only about the prevalence of sin, but also about the origin of such evil, how it came to pass on all humans, and the responsibility and judgment that each person will have to face. Thus, while there is virtually a universal agreement on what we would call the consequences of original sin, all the other claims have been called into question in the last centuries.

It is important for us to define more precisely what we mean by "original sin", and I will investigate this in two steps: first, I will explore two of the most important Reformed documents, the Belgic Confession and the Heidelberg Catechism. Second, I will characterize original sin as a central part of the Christian narrative. 


\subsection{The Augustinian/Reformed Understanding of Original Sin}

It is common to hear that Augustine was the "inventor" of original sin, at least as it has been understood in both Roman Catholic and Protestant confessions. ${ }^{2}$ Nevertheless, there is theological and historical evidence that Augustine was more a compiler of previous theological insights than the creator of the doctrine. ${ }^{3}$

But what was the Augustinian understanding of it? In a nutshell, it is the blending of three interconnected notions: first, the existence of an "original couple in a blessed state; [second] their fall into sin; [and third] the subsequent sinfulness of all their offspring, encompassing the totality of humans" (Van den Brink 2018, p. 117).

The Belgic Confession (BC) and the Heidelberg Catechism (HC) are not much more than an exposition and rehearsal of these three main insights. On the first element, that humans were created in a blessed state, the BC makes three affirmations: that God "created human beings from the dust of the earth", that they were created in "his image and likeness", i.e., "good, just and holy", and that this state enabled them "to conform in all things to the will of God" (BC14). The HC restates the second and third affirmations (HC Q\&A 6).

The second element described above is the affirmation that the first humans "fell into sin". The BC defines that in terms of actions: "they subjected themselves willingly to sin", and "they transgressed the commandment of life" (BC14).

2 This view is put forward, for example, by Schneider (2012).

3 Andrew McCoy has presented a sound argument for how Irenaeus, sometimes credited as the narrator of a different story of the fall, developed a notion of original sin that was later used and developed by Augustine (McCoy 2014).

Manuscrito - Rev. Int. Fil. Campinas, v. 44, n. 4, pp. 261-292, Oct.-Dec. 2021. 
The catechism is even shorter, answering where the corruption came from: "the fall and disobedience of our first parents" (HC Q\&A 7). Central to both documents is that an event occurred, as a result of the free choice of humanity's first pair, Adam and Eve, by whom the first sin was committed. It strongly implies that "sin is not "natural" (Smith 2017, 53), but rather an intrusion in the good creation of God. We can call this the "originating sin" (pecattum originans) (Van den Toren 2018a, 176), the very first sin ever perpetrated, which "somehow catalyzed all subsequent sinfulness" (Hays and Herring, 2013, 33). ${ }^{4}$

The third element is the "subsequent sinfulness of all their offspring", which we can name "originated original sin", which in turn "refers to the reality that every human in the world as we currently know it is born into sin" (Van den Toren 2018a, 176). This element is better understood as a conjunction of four allegations:

A) Consequences: As a result of the first sin, the first pair "separated themselves from God", "corrupted their entire nature", were "guilty", subject to "physical and spiritual death", and lost "all their excellent gifts" (BC14). These are the consequences that the first pair suffered because of their

\footnotetext{
${ }^{4}$ Hays and Herring $(2013,33)$ state that "a supposed result of this 'originating sin' was a proclivity to continue to sin, a desire to do wrong, which we call 'concupiscence"'. This entails the transmission that we will mention henceforth. They argue, however, that it is possible (and maybe even demanded by a historical-critical reading of Genesis and Romans) to construct the doctrine in a way that (1) holds on to the ubiquity of sin and concupiscence while (2) denying that there was an originating sin. In other words, we can account for the human inclination to sin without recourse to a literal event. While their position has exegetical and theological merits, it will not be investigated in this paper as long as its focus is on Augustinian/Reformed version of original sin, that clearly requires an originating $\sin$.
} 
sinful act. As the confession states, "This fall has so poisoned our nature" (HC Q\&A 7).

B) Transmission: Not only did the original pair suffer consequences from their sin, but also the rest of humanity, who inherited their state of sinfulness, are now "conceived and born in a sinful condition" (HC Q\&A 7), and "by the disobedience of Adam original sin has spread through the whole human race", which is "an inherited depravity which even infects small infants in their mother's womb" (BC 15). Worthy of note is that neither BC nor HC explains how this transmission occurred and occurs. Augustine defended that it happens through sexual reproduction, but since the confessions do not put it forward, Augustine's view on this point can be considered accidental rather than essential to the doctrine.

C) Enslavement: The descendants of Adam and Eve virtually all humanity - are so bound to sin that they cannot help but find themselves in a state of enslavement, so that "humans are nothing but slaves of sin" (BC14), and "we are so corrupt that we are totally unable to do any good" (HC Q\&A 8). In Augustinian language, before the first sin humans were able not to sin (posse peccare, posse non peccare), but after the original sin, they were not able not to sin (non posse non peccare).

D) Guilt: One of the consequences of the first sin (as described in A), is guilt, i.e., the first pair was deemed guilty by their error, and also every human being.

Now we can present a summary of the ART understanding of original sin as a set of three insights, better described as a cluster of six statements on the human condition. The first insight is not itself part of the doctrine but pivotal to its comprehension: the primeval state of blessedness in which humanity was created; the second is what was called "originating sin", and the other four compound what was called "originated original sin." Thus 
we can sum it up as follows: (i) the existence of an original blessed couple, created in the image of God who gave them a series of gifts, so that they were able to obey God's will and live a blessed life; (ii) this first couple committed, in an event, the first sin ever perpetrated, even though they had the ability not to do it (the originating sin); (iii) as a consequence of that sin, they fell from their original state, losing the gifts God had endowed them, and finding themselves in a corrupted state, not being able anymore to live in accordance to God's will; (iv) this fallen state was transmitted to their descendants and to every other human being; (v) all humans are enslaved to sin for they have inherited original sin; and (vi) all humans inherited the guilt of the first pair.

\subsection{The Narrative of Original Sin}

Important as Christian propositional doctrines may be, the Bible presents its major themes in narrative form. The doctrines are, in fact, theological explanations of the larger ongoing action of God in restoring creation and humanity. As James K. A. Smith puts it, "The doctrine of original sin and the historical understanding of the Fall is woven into the fabric of a story that is ultimately the drama of God's gracious interaction with humanity" (2017, p. 50).

In Reformed circles the narrative has been understood as creation, fall into sin, redemption, and consummation. This can be summarized as: God created a good world and humans in his own image to mirror his wisdom, love, and creativity as they would unfold the potentialities of creation; humanity, at a certain point, was unfaithful to its God-given vocation, and fell into sin; then, God started his project to rescue humanity from its plight in order to fulfill his purposes for creation, which he accomplished in the life, 
death, and resurrection of Jesus Christ, and which he will finally conclude in Jesus' second coming. ${ }^{5}$

Within this narrative, original sin corresponds to the second element, and it is crucial both backwards and forwards. Backwards because if original sin did not happen, what explains the actual reality of sinfulness that we experience, that, as Chesterton says, is evident for everyone? Does that mean that creation itself is, in a certain sense, evil? And the God who created it, is he to blame for this evil? Thus, a denial of original sin impinges on both the goodness of creation and the character of God, the creator. And forwards for, if we humans are not trapped in sin, what exactly did Jesus accomplish? Do we still need to be saved?

Yet, there is another and much more specific account widespread in evangelical circles. This narrative is nothing more than a narrower version of the one presented above, , and it is usually called "Young Earth Creationism". It goes as follows: Around 6,000 years ago God created the first human beings: Adam from the dust of the earth, and Eve, from one of Adam's ribs. Both acts were single, miraculous interventions of God into the natural order that cannot be described by natural means. They were created in a perfect state and in a perfect world, finished and functional, where death, pain, struggle, or any kind of moral and natural evil had no place whatsoever. This continued until Eve, listening to the counsel of the serpent, ate the forbidden fruit and shared it with Adam. As a consequence of this act, God cursed them and the entire creation, so that death, pain, and struggles were, from that point on, part of human's daily experience. Further, Adam and Eve, who are the only progenitors of humanity's genetic pool, transmitted their condition to the following generations.

5 For a fuller account of this narrative, see Bartholomew and Goheen (2004). 
I will not go along with the end of the story, for it suffices for our purposes. As we will see next, this particular account of human origin and plight is obviously contradicted by ET's claims. However, this is not the story we are primarily occupied with, for it is a product of a specific hermeneutic and a specific theological commitment, and not the required story by the ART.

\section{Part 3: Major Challenges Evolution Brings to Original Sin}

\subsection{Pinpointing the Conflict}

In Part $1 \mathrm{I}$ described ET in terms of nine claims, and in Part 2 I described original sin in terms of six statements as well as a critical part of biblical (particularly as interpreted in Augustinian/Reformed quarters) narrative. In which sense is original sin threatened by ET, if it is? Let's start by analyzing each of the six doctrinal statements of original sin. [See the appendix at the end of this essay for a summary of these lists. It may be helpful to have it at hand while you read the rest of this essay].

There are two possible challenges that impinge upon "i" (which concerns humans' initial condition): a denial that a primordial blessed state has ever existed and the affirmation that humanity emerged not as one single couple (Adam and Eve). The former can be challenged by "1", "2", " 3 ", "8", and "9". If by "original blessed" state we understand that the first humans were made by a miraculous creation of God (that disrupted the natural order), then " $\mathrm{i}$ " is in fact challenged by " 1 " (and consequently by " 2 " and " 3 ", which are the 
mechanisms by which evolution occurs). ${ }^{6}$ Also, if we understand "blessed state" as a "perfect state", where death, pain, struggle, or any kind of moral and natural evil had no place, then " $i$ " is also challenge by " 8 " and " 9 ".

However, this does not need to be the case. The Augustinian/Reformed picture of the prefallen state does not require us to defend that humans were created ex nibilo, although it may require a certain special action by which God granted the first Homo sapiens his image. For this reason, ET's claims "6" and "7" present no particular problem as well. In a certain framework, it is possible to conceive of humans biologically sharing genetic heritage with other species, and death (" 8 ") being present before humanity has acquired God's initial blessings. We can conclude that, in this sense, "i" is not intrinsically challenged by ET.

Yet there is the second affirmation contained in "i", that all humans are (biologically) descendants of a single couple, Adam and Eve. And although the confessions do not give much emphasis on it, they do assume it. Thus, we can say that there is a conflict between " $\mathrm{i}$ " and " 5 " - the affirmation of the initial bottleneck of 10,000 people.

ET affirms that many traits considered as sinful were part of the fabric of nature inherited by humans ("9"), what seems to be at odds with "iii", for, "if the human is a latecomer to the long history of evolution, a human fall into sin cannot be blamed for the existence of death and decay" (Van den Toren 2018b, pp. 111).

Yet there are at least three reasons why this point should not be considered too problematic. First, if there was a certain moment when humans, while biological heirs of previous species, received a special blessing from God which

${ }^{6}$ Further, both $\mathrm{BC}$ and the $\mathrm{HC}$ say nothing about the age of the earth, or for how long humans have been present in the world. Thus, "4" presents no critical challenge. 
enabled them to restrain some of their inherited traits, that moment "could have been extremely brief", and then "direct knowledge of such a state is extremely unlikely even in principle, and scientific findings have no bearing on this issue" (Pinsent 2018, p. 140). It applies also for "iiil" (the fall as a consequence of the first sin), even for physical human death as a consequence of sin. Second, considering the animal world, there is a vast range of biblical texts (e.g., Psalms 104:20-22; Job 38:39f; 39:26-30; 41:6) that attest to the "naturalness" of such traits, as part of "God's good creation" (Jaeger 2017, p. 28). Third, while Genesis implies and Paul affirms (see Romans 6:23 and Romans 5:12-21) that human death was a consequence of sin, we could argue that eternal life was a special gift from God rather than part of human natural makeup, ${ }^{7}$ and thus it would not be at odds with " 8 ".

Arguably, the point of greater conflict is "iv" (the transmission of original sin). First there's the problem presented by " 5 ", for, how would we all inherit the fate of one couple if we are not all descendants of just one couple? Here there seems to be a genuine conflict. Further, how would the transmission have occurred? And what exactly was (and is) transmitted? These questions, I will argue, present no significant challenge. For now, it is sufficient to say that one possible solution is that humans inherit not a particular gene or disposition to sin, but rather a lack of the spiritual gifts necessary to develop a virtuous life, ${ }^{8}$ at the same time that they inherit a series of social, cultural, and spiritual fallen conditions that are now deeply interwoven into the fabric of their humanness.

\footnotetext{
${ }^{7}$ For a sound exegetical argumentation on this position, see $\mathrm{J}$. Middleton (2017).

${ }^{8}$ This is the suggestion of Pinsent, "Original sin consists principally in the absence of a supernatural gift of grace" (2018, p. 140).
} 
And what about the affirmation "v", that we are enslaved to a sinful state? It seems that this affirmation is rather confirmed than contradicted by ET, which argues that human nature is deeply bound to our "natural" tendencies of aggression, egoism, and self-preservation (" 9 "). Certainly, the human predicament is not reduced to such descriptions, for it includes social and spiritual dimensions as well, which are not easily described in the language of natural sciences.

Finally, we must consider "vi", the inheritance of the guilt from our first parents. As problematic as it might be, ET is not one of its causes. As van den Brink says, "the reason for this rejection is once again unrelated to evolutionary theory but is instead the sheer counterintuitiveness of being held responsible for the sin of someone else" $(2018,126)$.

It is now worth presenting a summary of the actual challenges ET posits to original sin, as we have traced so far. Statements "iil", "iiil", and "vi" are relatively untouched by ET, while " $v$ " seems to be rather confirmed. There are conflicts, thus, in "i" and "iv", related mainly to " 5 ", as it raises questions on the initial human population and how the first sin was transmitted. Thus, we have narrowed down the supposed problems to a much simpler set of questions. But there is still an important matter to deal with: the clash of narratives.

The Reformed account of the biblical narrative, as presented in Part 2, has a clear threefold structure: creation - fall - redemption (and subsequent consummation). ET, on the other hand, presents a linear narrative, of an evolving nature from less complex towards more complex biological entities, and, on human origins, a story in which humans are natural products from former species. The clash could come from the biblical affirmation that sin, and the postfallen state, was introduced into the world through a single act, an extremely short-period event, while ET tells that much of what is counted as "fallen state" was part of the fabric of the 
world since its beginnings, and, in terms of human behavior, that those "evil" traits came gradually throughout the evolutionary process. As Pinsent points out, "the key issue is this: Augustine clearly thought of the fall as an event ... it was a primeval disaster at the beginning of the human race, the effects of which have henceforth been propagated ... to every human alive" (2018, p. 137).

Pinsent names it the problem of "gradualism" (2018, p.138), a supposed dissonance between the very slow story of ET (where there is "no evidence of a prefallen state in which humans were morally and physically perfect") and "the consequence of a single, freely chosen action" (2018, p. 141) described in the Christian narrative. In other words, ET, in this aspect, is a competing story. This is a serious issue that we have to deal wtih.

\subsection{Accounts of Incompatibility}

For a great many people, the described conflicts are simply insoluble. I now briefly sketch some representative positions, which can be divided into two main groups.

There are, from one side, authors who deny ET: either Young Earth Creationists, Old Earth Creationists, or proponents of Intelligent Design, ${ }^{9}$ they are joined together in rejecting some or all affirmations of ET. There is no agreement among them as to what are, exactly, the weaknesses and flaws of ET. Some challenge the consolidated evidence (Johnson 1991), others discuss problems on scientific methods used in ET (Behe 2006), while others simply state that ET does not conform to the plain teachings of the Bible (Wood and Falk 2019). When we

\footnotetext{
${ }^{9}$ E.g., for a solid presentation of each one of these positions, see J. Stump (2017).
}

Manuscrito - Rev. Int. Fil. Campinas, v. 44, n. 4, pp. 261-292, Oct.-Dec. 2021. 
zoom in on their interpretations of human origins and the intrusion of sin into humankind, we find a plurality of interpretations and approaches; actually, the only thing that holds them together is the high suspicion on the epistemic reliability of ET.

On the other side, there are theologians who, while finding no possible compatibility, have offered theological interpretations of human origins, fall, and salvation which remove original sin from the narrative of the Christian story. ${ }^{10}$ To use the language employed in Part 2, they deny the need of an "originating sin" in order to acknowledge the reality of the consequences of sin ("originated original $\sin ") .11$

The elements which each of these authors retain or abandon vary, yet we can offer a simple, twofold picture of their view: they affirm that humans are part of the fabric of natural history, and that no particular event (no "originating sin") took place which triggered the postfallen effects. As van den Toren says, "a number of theologians ... have proposed that original sin is a theological term for the destructive biases inherited from our prehuman evolution" (2018a, p. 184).

This, simply put, is to equate original sin with "9", while abandoning "i" and "iil" entirely. Present in the argumentation of virtually all these authors is the idea that the doctrine of original sin is nowhere present in the

10 Clearly, some of them retain the term "original sin" in their theological description, while capitulating to the idea that there was no disruption between a good creation and a postfallen humanity.

11 This idea is well explained by Harlow: "More pervasive in and essential to biblical teaching ... are Scripture's statements concerning the reality and effects of sin, the unity of the human race in the grip of $\sin$, and the universal need for redemption from sin in Jesus Christ" (2010, p. 191). 
Genesis's accounts, but rather it is a later add-on to Christian theology (Harlow 2010, p. 187). As representatives, Denis Lamoureux calls for a "revolution" in biblical interpretation (2015), Peter Enns emphasizes the mythical, nonhistorical value of Genesis 1-3 (2012), and John Schneider insists on a different, Irenaean interpretation of Genesis, which in his view does not require a prefallen state (2012).

All these alternatives, however, end up naturalizing human evil and the sinful state, avoiding a conflict with ET, but deviating from the biblical narrative. They reject "ii", and along with it the Augustinian/Reformed account of the biblical doctrine of sin. Furthermore, as Smith puts it, "such models seem to run afoul of making the order of redemption contra the order of creation; that is redemption ... would seem to require undoing rather than restoring creation" (2017, p. 60). Now we turn for a possible harmonization between ET and original sin.

\section{Part 4: Original Sin and Evolution: Vice and Virtue as the Ways to be Human}

In this final section my suggestions will be more tentative in character. I will proceed as follows: first, I will explore what we can understand by "Adam and Eve", either as representatives (real couple) or as the initial human community. Second, I will discuss the difference between a primeval state of "blessedness" and of "perfection". Third, I will present the possible scenarios for the meanings of "blessed state" (“i”) and "image of God". And fourth, I will deal with the question of the original sin itself ("iii") and its possible ways of transmission ("iv"). 


\subsection{How to understand Adam and Eve?}

There is a widespread consensus that Genesis 1-11 contains mythical language and is based on, and critical to, the "cultural river" cosmologies that were common in the ancient Near East (Walton and Longman 2018, pp. 61-90). Genesis 1-11 can be considered as a "theological commentary on and partially symbolic reconstruction of primal history using the concepts and re-renderings of the various stories around at the time, such as the Babylonian Gilgamesh epic" (Collins 2019). The names "Adam" and "Eve", for instance, have clearly symbolic meanings (Walton and Longman 2018, pp. 58-62). Does this mean that the whole portion of Genesis 1-11 has no historic value?

Paul, for instance, clearly seems to believe in a literal Adam in his argumentation in Romans 5:12-21. James Dunn's seminal commentary on Romans (1998) challenges this assumption, though. Yet, for our purposes it is sufficient to understand that for biblical writers myth and history are not antagonistic categories. A certain event could be narrated vested with mythological elements in order to convey theological truths that would otherwise remain veiled. This comprehension pushes us back from strictly literal interpretations, while not allowing us to completely "dehistoricize" old stories. So, what are the possible scenarios?

From "5" we know that "humans emerged from prehuman ancestors in times immemorial as a group rather than as a couple" (Van den Brink 2018, p. 126), and thus a single couple that are the "biological parents" of every human being is ruled out as a feasible option. ${ }^{12}$ But, if we

${ }^{12}$ It is worth mentioning the recent work of Swamidass (2019) that disentangles genetic and genealogical ancestry, providing thus a scientific reasonable, and theological intelligent, way of 
want to retain some historical ground for Adam and Eve, we can still consider three major plausible scenarios. ${ }^{13}$ In the first scenario, Adam and Eve correspond to the whole initial bottleneck (of about 10,000 individuals). One important voice who defended this view was Karl Rahner, for whom "Adam" and "Eve" were terms "designating the first human population that got a real consciousness" (Van den Brink 2018 , p. 127) and who, for the first time, acquired moral awareness.

Then we have the representative view, which in turn can function in two ways: old representatives and early representatives. The former (second scenario) defends the notion that Adam and Eve were a representative couple, from the original bottleneck, who were the leaders of that group, and who first received God's revelation and were endowed with his image. The latter (third scenario) defends that, while Homo sapiens have existed for more than 200,000 years ("4"), it was not until recent times, probably sometime during the Neolithic about 7,000 years ago, that God elected a couple and impinged his image on them, making them the very first humans to know God and to be accountable before him. In both representative views, "Adam and Eve are supernaturally upgraded from hominids to bear God's image" (Collins 2018, p. 157).

understanding the connection between a primeval couple and their descendants. [I thank one of the reviewers for this suggestion]

${ }^{13}$ It is important to make it clear that even for the scenarios that try to retain some historical ground for the narratives of Genesis 1-3 there is no commitment with a scientific concordist reading, and that is so on the basis that all scenarios presented in this paper acknowledge that the Genesis text has no scientific purpose or nature. 


\subsection{Blessed, not Perfect}

It is important to note that none of these three scenarios require a state of perfection. This idea was already put forward by Irenaeus (McCoy 2014), for whom the initial creation, although good and blessed, was created in infancy and in an immature state, as were the first humans, Adam and Eve. God's unified plan was to make them grow up to the perfect stature of Christ, the telos and ending of all creation. Such understanding makes "i" suitable with "8" and " 9 ", since it does not require a perfect world, but only a state of blessedness for the bearers of God's image. Yet we still need to understand what exactly were the "image" or "gifts" that enabled them to live the life God intended from the beginning.

We can now analyze, for each scenario, the questions of (i) image of God, (ii) originating sin, and (iv) transmission of sin. I will present two models for these analyses, and the following chart summarizes the possibilities: 


\begin{tabular}{|c|c|c|c|}
\hline \multirow{2}{*}{$\begin{array}{c}\text { Model / } \\
\text { Scenario }\end{array}$} & $\begin{array}{c}\text { Scenario 1: } \\
\text { Whole } \\
\text { bottleneck }\end{array}$ & $\begin{array}{c}\text { Scenario 2: Old } \\
\text { Representatives }\end{array}$ & $\begin{array}{c}\text { Scenario 3: Recent } \\
\text { Representatives }\end{array}$ \\
\cline { 2 - 4 } & & \\
$\begin{array}{c}\text { Model A } \\
\text { Jaeger) }\end{array}$ & & \\
Model & (i) image of God \\
B & (ii) originating sin \\
(Multi- & (iv) transmission of sin \\
level) & & \\
\hline
\end{tabular}

Chart 1: How each of the three scenarios is developed in Models A and B. Each combination of model / scenario presents a distinctive picture of items (i), (ii), and (iv), which is described below.

\subsection{Imagebearers}

I present two major positions on this point. Model A, well-articulated by Lydia Jaeger, represents an actualized version of Aquinas/Calvin's proposal. For her, humans inherited a nature full of tendencies ("9") that would make them sinners, but received a supernatural gift from God that enabled them to love and obey him $(2017,32)$.

This account has the advantage of being compatible with the three scenarios described above, and virtually immune to scientific critiques, since what is acquired (and then lost at 
"originating sin") is a spiritual gift ("excellent gifts", as described in $\mathrm{BC}$ ), that, while functioning as "the integrating centre of human nature" (Jaeger 2017, p. 31), could not itself be confused with anything in the natural domain. The issue with Jaeger's model is that it seems to put forward a strong split between the realms of nature and grace, which is at odds with the strong emphasis on the integration between nature and grace in the Reformed tradition ${ }^{14}$ (Van den Brink 2020, p. 28).

Model B, which I call emergent-multilevel model, is a more nuanced, integrated notion of the human capabilities and moral aptitudes, ${ }^{15}$ which works better for the first scenario- the one which makes Adam and Eve correspond to the entire initial bottleneck. The inherited inclinations were not "themselves evil since they can often lead to beneficial actions, such as keeping oneself alive" (Collins 2019). ${ }^{16}$ Human beings, at a certain point, acquired awareness of God and moral responsibility upon the rest of creation, which could have come either through natural emergence development—guided by God—or through a special act of revelation. At that point, they were "subject to various temptations arising both from the desires and instincts they inherited from their evolutionary past and from various new possibilities for self-centeredness, selfidolization, self-denigration" (Collins 2019), but had the

$14 \mathrm{On}$ the relation between nature and grace in ART, see the seminal work by J. Veenhof (2006).

15 This model has several resemblances with Robin Collins' historical/ideal model (2019).

16 So, although natural tendencies are not, by themselves, evil, the evil that human beings exhibit is not natural either. Rather, human evil emerges in a complex web of moral choice, cultural assimilation, and spiritual resignation, as I will make clear. 
possibility to refrain those tendencies and use their moral, relational, and spiritual capacities to fulfill their God-given task to unfold the potentialities of creation mirroring God's wisdom, justice, and love. But they didn't.

\subsection{Originating Sin and its Transmission 4.4.1. Jaeger's Model (A)}

In scenarios two and three (representatives), it is easy to describe the originating sin: the representatives committed it ("iii") at a certain point of their lives. But a whole horde of questions arises: how (in the first scenario) was it transmitted to the other 10,000? In scenario three, when the human population was much greater and was spread throughout the continents, the transmission seems even more implausible. The usual answer is contained within the term "representative": such as the representative couple received God's revelation and through them all other people, in the same way the representative couple sinned and, through their representation, all others "sinned" along with them, and cosuffered the consequences. The advantage of this model is that it solves both the problem of the first sin and of its transmission.

\subsubsection{Emergent-Multilevel Model (B)}

In the first scenario, expressed now in the emergentmultilevel model, human and creation flourishing depended on human's response to the constraints of their inherited nature as well as their spiritual response to their God-given, socially developed abilities to love and carry on their task of being wise stewards of creation. As I have hinted, those 
abilities could emerge through natural processes, and/or have been given directly by God.

The idea of "loving" God and one another encapsulates humanity's overall task, since to love is to learn a path, to develop the dispositions we have received to their fullest. It is to work on the marvelous, stubborn natural material of which we ourselves are made, in a way that we may achieve the summit of humanity's intrinsic possibilities. It is important to see that the natural constraints and inclinations are not only "temptations", as things that one must deny to obey God, but also, as muscles that need to be trained to mature, our inclinations should be properly trained in order to become dispositions and competences (virtues) that would enable us to love. "Adam and Eve", understood as the whole initial population, were blessed so that, if they had remained without sin, they would have grown into a virtuous life, ordering their desires in the right way, loving properly God and one another, and carrying on God's wise purposes for the world.

Two questions remain: how the first sin happened and how it was transmitted. For the first question, Smith's distinction between punctual and temporal fall is helpful. He explains that, to be faithful to the Christian narrative, we can advance the idea that the originating sin was, in fact, a series of small choices against God that took place in the primeval human community (2017, pp. 61-62), which made their virtuous future become a vicious present. Thus the "originated sin" was not a single act, but rather a conjunction of actions and choices made in a certain primeval period.

With this in view, it is important to understand that humanity, even its first community, could not (and cannot) be reduced to individuals and their individual choices. Actually we inhabit a multilevel existence, in terms of individual, relational-familiar, cultural and spiritual dimensions. Sin, in this broad view, is not only "giving up" 
our natural tendency for, e.g., aggression, but rather diving in deeper ways of evil "such as self-idolization, selfcenteredness, self-hatred and denigration" (Collins 2019). After the "originating sin" (or after the first period of time corresponding to it), it was not humanity's genetic pool that suffered corruption, but rather all these dimensions.

This multilevel comprehension of humanity's existence helps us to envisage the complex mode of sin's transmission. Van den Toren's piece on cultural transmission is very helpful, as he points out,

Cultural socialization may be one of the mechanisms ... for understanding the working of the inheritance of sin from the generations before us: we can only grow up as humans if we are socialized and enculturated within a specific family and community from which we inherit a culture both for good and for evil ... I can only become a fully developed human by imbibing the culture of my parents. I appropriate their ways of behavior, I inherit their tools and living environments, I am socialized in the social structures in which they function, and I inherit the symbolic universe with which good and evil values ... both truthful and distorting aspects of their symbolic universe, both the blessing and the curse of their understanding of life inscribed in their practices and language (Van den Toren 2018a, p. 182).

Love, virtue, and wise stewardship are terms that capture the path that was before the very first community of humans, who were blessed enough to recognize God the creator, and had the opportunity to journey in obedience and relationship 
with him. The fracture caused by their sin was irreparable because it affected each structure of our existence, rendering us incapable of a full relationship with God and one another, because some of our natural tendencies became demonic within ourselves, and the institutions we have built since then could not help but to mirror their "tainted creators". We were, and are, trapped in sin. Original sin, in its historical, spiritual, and theological meaning, is here.

\section{Conclusion}

In this paper I argued that it is possible to remain faithful to the core of the Augustinian/Reformed picture of original sin and to accept the science of evolution. Chart 1 presents the main options. There are three possible scenarios to interpret "Adam and Eve" - as (1) the whole initial human bottleneck, (2) old representatives, and (3) recent representatives. Each one of these three scenarios, in turn, may be developed by two models - (A) Jaeger's and (B) Multi-level. The match between scenarios and models totalizes six different ways to interpret the doctrine of original sin sympathetic to ET, each one with a characterization of (i) image of God, (ii) originating sin, and (iv) transmission of the originating sin. While both models have virtues, I favored (B) Multi-level as long as it provides a more integrated picture of natural processes and divine guidance. I have also argued that Multi-level model seems to work better with scenario 1 , in which the whole initial bottleneck acquired (i) the image of God through an emergent process (that may have been triggered by a special act of God), which allowed them to develop biological instincts in a virtuous life; they (ii) committed the originating sin not as a single act, but through a series of acts in a certain amount of time that disrupted the harmony of that 
population within themselves, with God, and with creation; (iii) the fallen condition was transmitted in a complex way, involving familiar, cultural, and spiritual dimensions.

\section{Acknowledgement}

Special thanks to Rev. Scott Hoezee, Dr. Roberto Covolan, and Rev. Guilherme de Carvalho, who were early supporters of this research and provided invaluable comments on earlier drafts. I also thank two blind referees for their helpful suggestions.

\section{References}

BARTHOLOMEW, C., and GOHEEN, M. The Drama of Scripture. Grand Rapids: Baker Academic, 2004.

BEHE, M. Darwin's Black Box: The Biochemical Challenge to Evolution. New York: Free Press, 2006.

CAVANAUGH, W., SMITH, J. Evolution and the Fall. Grand Rapids: Eerdmans, 2017.

CHESTERTON, G. K. All Things Considered. Scotts Valley, CA: CreateSpace Independent Publishing Platform, 1915.

COLLINS, J. “Adam as Federal Head of Humankind”. In S. Rosenberg (ed.) (2018), pp. 143-159.

COLLINS, R. "Evolution and the Original Sin: The Historical/Ideal View", BioLogos. accessed April 28, 2019. https://biologos.org/articles/evolution-andoriginal-sin-the-historical-ideal-view, 2014. 
DUNN, J. Romans 1-8 (WBC38A). Nashville: Thomas Nelson, 1988.

ENNS, P. The Evolution of Adam: What the Bible Does and Doesn't Say About Human Origins. Grand Rapids: Brazos Press, 2012.

FALK, D. "Human Origins-The scientific story". In W. Cavanaugh and J. Smith (eds.) (2017), pp. 3-22.

HAYS, C., HERRING, S. “Adam and the Fall”. In C. Hays and C. Ansberry (eds.) (2013), pp. 24-54.

HAM, K. "Young Earth Creationism". In J. Stump (ed.) (2017), pp. 17-48.

HARLOW, D. "After Adam: Reading Genesis in an Age of Evolutionary Science". Perspectives on Science and Christian Faith 62: 179-95, 2010.

JAEGER, L. "Models of the Fall Including Historical Adam as Ancestor of All Humans: Scientific and Theological Constraints". Science \& Christian Belief 29: 20-36, 2017.

JOHNSON, P. Darwin on Trial. Washington: Regnery Publishing, 1991.

LAMOUREUX, D. "Beyond Original Sin: Is a Theological Paradigm Shift Inevitable?" Perspectives on Science and Christian Faith 67: 35-49, 2015.

MCCOY, A. "Becoming Who We are Supposed to Be: An Evaluation of Schneider's Use of Christian Theology in Conversation with Recent Genetic Science". Calvin Theological Journal 49: 63-84, 2014.

MIDDLETON, R. "Reading Genesis 3 Attentive to Human Evolution: Beyond Concordism and NonOverlapping Magisteria”. In W. Cavanaugh and J. Smith (eds.) (2017), pp. 67-97. 
Our Faith: Ecumenical Creeds, Reformed Confessions, and Other Resources. Grand Rapids: Faith Alive, 2013.

PINSENT, A. "Augustine, Original Sin, and the Naked Ape”. In S. Rosenberg (ed.) (2018), pp. 130-142.

ROSENBERG, P. Finding Ourselves after Darwin: Conversations on the Image of God, Original Sin, and the Problem of Evil. Grand Rapids: Baker, 2018.

SCHNEIDER, J. "The Fall of the 'Augustinian Adam': Original Fragility and Supralapsarian Purpose." Zygon 47: 949-69, 2012.

SMITH, J. "What Stands on the Fall-A Philosophical Exploration". In W. Cavanaugh and J. Smith (eds.) (2017), pp. 48-64.

STUMP, J. Four Views on Creation, Evolution and Intelligent Design. Grand Rapids: Zondervan, 2017.

SWAMIDASS, J. S. The Genealogical Adam and Eve: The Surprising Science of Universal Ancestry. Downers Grove: Inter Varsity Press. 2019.

VAN DEN BRINK, Gijsbert. "Questions, Challenges, and Concerns for Original Sin". In S. Rosenberg (ed.) (2018), pp. 117-129.

. Reformed Theology \& Evolutionary Theory. Grand Rapids: Eerdmans, 2020.

VAN DEN BRINK, G., DE RIDDER, J., WOUDENBERG, R. "The Epistemic Status of Evolutionary Theory." Theology and Science 15:4, 45472, 2017.

VAN DEN TOREN, B. "Original Sin and the Coevolution of Nature and Culture”. In S. Rosenberg (ed.) (2018a), pp. 173-186. 
. "Part 2: Original Sin and Evolution." In S. Rosenberg (ed.) (2018b), pp. 111-116.

VEENHOF, J. Nature and Grace in Herman Bavinck. Translated by Albert M. Wolters. Sioux Center, IA: Dordt College Press. 2006.

VENEMA, D., MCKNIGHT, S. Adam and the Genome. Grand Rapids: Brazos Press, 2017.

WALTON, J. The Lost World of Adam and Eve: Genesis 2-3 and the Human Origins Debate. Downers Grove: Inter Varsity Press. 2015.

WALTON, J., LONGMAN, T. The Lost World of the Flood: Mythology, Theology, and the Deluge Debate. Downers Grove: IVP Academic, 2018.

WARD, K. God, Faith and the New Millennium: Christian Belief in an Age of Science. Oxford, UK: Oneworld, 1998.

WOOD, T., FALK, D. The Fool and the Heretic: How Two Scientists Moved Beyond Labels to a Christian Dialogue about Creation and Evolution. Grand Rapids: Zondervan Academic, 2019.

\section{Appendix}

Six Statements on the Augustinian/Reformed view of original Sin:

(i) original blessed couple;

(ii) this first couple committed the first sin ever perpetrated;

(iii) as a consequence of that sin, they fell from their original state;

(iv) this state was transmitted to their descendants and to every other human being; 
(v) all humans are enslaved to sin for they had inherited the original sin;

(vi) all humans inherited the guilt of the first pair.

ET on Human Origins:

1) the Homo sapiens shares a common ancestry with all other species

2) the main mechanism that drove our development was natural selection;

3) random mutations were the means by which our biological ancestors acquired new traits

4) our species first emerged in Africa between 300,000 and 200,000 years ago;

5) our species did not emerge as a single pair of individuals;

6) many other hominid species existed before our own had emerged;

7) there was interbreeding between our species and other hominid species;

8) death was present in the natural world much before our species emerged;

9) traits such as hunting, aggression, sexual promiscuity (among others) were inherited by our species from our biological ancestors and were important characteristics for the success (preservation) of our species.

$(\infty) B Y$

Manuscrito - Rev. Int. Fil. Campinas, v. 44, n. 4, pp. 261-292, Oct.-Dec. 2021. 